\title{
Organizational Change: Using Academic Accreditation in Transforming EFL Programs in the Saudi Context
}

\author{
Anas Almuhammadi ${ }^{1}$ \\ ${ }^{1}$ English Language Institute, King Abdulaziz University, Jeddah, Saudi Arabia \\ Correspondence: Anas H. Almuhammadi, English Language Institute, King Abdulaziz University, 80200, Jeddah, \\ Saudi Arabia. Tel: 966-565-000-484. E-mail: aalmuhammadi@kau.edu.sa
}

Received: March 1, 2017 Accepted: May 20, 2017 Online Published: May 26, 2017

doi: 10.5539/elt.v10n6p128 URL: http://doi.org/10.5539/elt.v10n6p128

\begin{abstract}
This study details the procedure and results of developing a mission statement at a language institute for the purpose of obtaining a program accreditation from an international language commission. A serious self-study process results in the development of a solid, true and ambitious mission since the mission covers all areas related to achieving students learning outcomes. It shows how the mission was changed and why. It also details how the new mission resulted in the improving quality, especially in the areas of curriculum and professional development of faculty and staff. Other aspects, such as facilities and student affairs were modified to achieve the goals and objectives of the new mission. This essay reports the changes that were implemented during the process of mission statement development. These changes resulted in plans to improve the quality of the English language teaching at the English Language Academy (ELA) which offers an English language program to Foundation Year students whose success in the program is a college requirement at the University of Business and Technology (UBT) in the academic year of 2016-2017. The program also aims at improving the English language proficiency of students so that they can use it in their future professions considering that the university logo is "Education for Job Opportunities." The third main goal or aim is related to the use of English to assist students in personal and social life. Critical thinking surfaced as a main concern of those surveyed for needs assessment. The report concludes with recommending conducting thorough and genuine self-study process which certainly ends with quality improvement. The report uses data collected from five questionnaires completed by students, faculty, alumni and employers of UBT graduates. The purpose of the survey was to identify the needs of the students. Based on those needs, the learning outcomes are identified and accordingly, the new mission statement is developed.
\end{abstract}

Keywords: accreditation, professional development, English language academy, University of Business and Technology, Saudi context

\section{Introduction}

\subsection{Introduce the Problem}

The English Language Academy (ELA) is part of the University of Business and Technology (UBT), Jeddah, Saudi Arabia; a university known for its graduates' proficiency in English which is required for job opportunities and entrepreneurship. The university slogan is "Education for Job Opportunities and Entrepreneurship." The brain image its main college, the College of Business Administration (CBA), has acquired business proficiency and leadership of graduates whose English is far more advanced than that of other university graduates, which has given them an important edge when competing for jobs in the local market. The mission statement was first developed in 2009 when the English Language Academy was established. To improve the quality and ranking, ELA decided to obtain program accreditation by an American commission known as the: Commission for English Language Accreditation (CEA) which is authorized by the American Department of Education to award accreditation locally and internationally (Commission on English Language Program Accreditation, 2017). Challenges of the self-study included the number of participating teachers in the exercise since they taught twenty hours a week; teachers were also assigned fifteen hours of office hours weekly. Another concern was to explore to what extent the standards are country-specific. This is particularly important since the standards were developed in English-speaking countries. Their main focus would be on the kind of English needed to function in an English-speaking country. In the ELA case, learning English is intended as enrichment to further advance 
students' college achievement, opening employment and job opportunities, and assist in personal life and community service. In this case, standards need to be adapted and modified from an English as a Second Language (ESL) to an English as a Foreing Language (EFL) context. This requires studying each standard and making sure it applies to our context. Since the standards had to be submitted to CEA, which is an accreditation commission for approval, a target date for that needed to be set. Other timelines needed to be determined taking into account the types of approval needed with short-term deadlines established and adhered to. The current research field deals with a new area of EFL in the Saudi context. To obtain the program accreditation from an internationally recognized commission, ensures the continuous quality and maintenance of the program.

\subsection{Objective of the Study}

The objective of this study is to document the various activities that took place during the self-study process required to obtain English language program accreditation. The first standard to be examined was the mission statement. Hence, the report shows how a mission is amended or developed taking into consideration the other standards that affect and are affected by the mission to develop a new mission for an English language institute to obtain English language program accreditation from an American commission that awards institutional accreditation for institutions and program within the US as well as worldwide. This will enhance the status and ranking of the university and attract prospective students. Developing a new mission requires serious self-study exercise which is detailed in this report.

\section{Method}

The researcher followed an analytical approach in this study. The main focus was on analyzing the data received from respondents without attempting at interfering with attitudes, perceptions or controlling the direction of intention of respondents. Five questionnaires were used as a quantitative method followed by qualitative analysis of the data to arrive at the findings.

\subsection{Procedure}

The old mission of the ELA was examined and compared to UBT's main mission to see if the old mission reflects the main goals and objectives of ELA and is in line with and supports the UBT's mission. The old mission of ELA was:

"The mission of the English Language Academy (ELA) at the University of Business and Technology (UBT) is to offer quality English language instruction and provide a student-centered intensive general English language program that will equip UBT currently enrolled students with the English language skills they need to acquire in order to succeed in their academic studies, advanced career training, and become competitive in today's job market."

The mission of UBT is:

"The University of Business and Technology (UBT) seeks to establish itself as a nationally and internationally recognized university in higher education though providing (1) quality education, (2) training and development, (3) scientific research, (4) fulfilling the labor market needs. In order to achieve these goals, UBT is committed to achieve quality, creative educational environment, administrative efficiency and effective professionalism by: Measuring and evaluating its performance in comparison with national and international universities; Specialized professional consultancy and joint projects; Continuous development and modernization; Developing an effective system for promoting inventions and innovations; Attracting outstanding faculty members; Creating and developing rules and procedures of good governance in all university activities; Supporting and encouraging student academic and non-academic activities; National and international partnerships with educational and research institutions; Running the university on an economic basis and implementing methods enabling the achievement of its goals; and Specialized training for students and alumni".

The main goals and objectives of the university mission include: entrepreneurship and leadership skills; breadth and depth of knowledge; solid analytical and communication abilities; team work and problem solving skills; personal commitment and social responsibility; social, moral and ethical values; and knowledge transfer from one context to another. Since the old ELA mission did not reflect those goals and objectives, it was decided to determine the goals and objectives of the ELA in a realistic and scientific manner, then develop a new mission to reflect those goals and objectives which correlate to the university ones. This was a requirement to meet the first standard of CEA's eleven standards to be awarded accreditation. CEA define the mission as follows: "The program or language institution has a written statement of its mission and goals, which guides activities, policies, and allocation of resources. This statement is communicated to faculty, students, and staff, as well as to prospective students, student sponsors, and the public, and is evaluated periodically." (CEA Standards, 2017, p. 
4) Adhering to the guidelines provided in CEA mission standard, an accreditation team was formed. It was also decided to consult NCAAA while developing the mission. The team found out that the old mission needed to be amended or changed. The team decided to conduct needs assessment to specify the goals and objectives of the mission by identifying the learning outcomes to be accomplished by the program. The guidelines also showed that the goals and objectives of the old mission were vague besides the fact that they did not support or aligned to the university's main mission. Thus, it was decided to amend the mission, taking into account that the new mission should consider the eleven standards required to be awarded program accreditation. The team took into consideration that the new mission should be clear and accessible for the students and the public as well as being precise to serve as a guide for planners and decision makers at all levels at ELA. The accreditation team decided to develop the new mission based on the university colleges English language requirement, the future job duties and responsibilities needs besides the personal and social ones. To determine those needs, the team developed five questionnaires to conducted a survey that covers the areas to be stated in the mission statement.

The five questionnaires are as follows:

1) A questionnaire that targets current students at ELA. Participants were 221 beginners to intermediate students.

2) A questionnaire that targets exiting students. Participants were 64 advanced students.

3) A questionnaire that targets faculty and staff at colleges ELA students are going to join. Participants were 22 faculty members.

4) A questionnaire that targets UBT alumni. Participants were 15 alumni.

5) A questionnaire that targets employers of UBT graduates. Participants were 15 employers.

The online SurveyMonkey® website was used as a tool for hosting the survey.

\section{Results}

Table 1. Analysis of the results of questionnaires \# 1,2 and 4 regarding the need to study English

\begin{tabular}{ccccc}
\hline & College Admission & Job Requirement & Social Interaction & Personal Needs \\
\hline 1. & $92 \%$ & $78 \%$ & $46 \%$ & $50 \%$ \\
2. & $88 \%$ & $90 \%$ & $53 \%$ & $54 \%$ \\
4. & $76 \%$ & $92 \%$ & $76 \%$ & $48 \%$ \\
\hline
\end{tabular}

Analysis of the results of questionnaires \# 1,2 and 4 regarding the need to study English were as follows:

So, the area of job requirement got the highest points while the requirement for college admission came second. Then, social interaction and personal use came third. These were decided to be reflected by the new mission statement. Other findings related to improving the quality of education surfaced while surveying the development of the mission since the mission covers most of the other standards, if not all. These areas had to be examined to find out how the new mission can be achieved. These are:

\subsection{Changing Curriculum}

Analysis of the results of question \# 10 in questionnaires \# 1, 2, and 3 regarding students' satisfaction with acquiring the skills of reading, listening, speaking and writing was as follows:

Table 2. Analysis of the results of question \# 10 in questionnaires \# 1, 2, and 3 regarding students' satisfaction with acquiring the skills of reading, listening, speaking and writing

\begin{tabular}{ccccc}
\hline $\begin{array}{c}\text { Results of the analysis of } \\
\text { responses to questions 13, } \\
14, \text { and 15 in questionnaires }\end{array}$ & Reading Skill & Speaking Skill & Listening Skill & Writing Skill \\
\hline Levels 1 to 5 students & $78 \%$ & $80 \%$ & $66 \%$ & $89 \%$ \\
Exiting students & $64 \%$ & $86 \%$ & $71 \%$ & $87 \%$ \\
Alumni & $67 \%$ & $91 \%$ & $70 \%$ & $80 \%$ \\
\hline
\end{tabular}


Results of the analysis of responses to questions 13,14, and 15 in questionnaires \# 3, 4 and 5 about conceptual, analytical and problem solving skills show the need to improve these skills and abilities. Results were as follows:

Table 3. Results of the analysis of responses to questions 13,14, and 15 in questionnaires \# 3, 4 and 5 about conceptual, analytical and problem solving skills

\begin{tabular}{cccccc}
\hline & Reading Skill & Speaking Skill & Listening Skill & Writing Skill & Critical Thinking \\
\hline Faculty & $71 \%$ & $38 \%$ & $73 \%$ & $58 \%$ & $84 \%$ \\
Alumni & $66 \%$ & $40 \%$ & $69 \%$ & $65 \%$ & $68 \%$ \\
Employers & $88 \%$ & $30 \%$ & $71 \%$ & $74 \%$ & $88 \%$ \\
\hline
\end{tabular}

The above tables show that the highest percentage of employers (88\%) emphasized the need for reading and critical thinking skills. Writing formal emails also rated high by employers and alumni. The listening skill also averaged more than $71 \%$ of respondents. A curriculum catering for the above needs was to be used. Thus, the old curriculum, basically grammar based, was changed into National Geographic textbooks Life ${ }^{\circledR}$ which puts emphasis on critical thinking and reading skills. Also, formal and informal emails are topics dealt with by Life ${ }^{\circledR}$. The audio and video components of this curriculum would remedy the listening need for improvement. Other topics, such as presentations and projects, were added to the curriculum to enhance both writing, speaking and critical thinking aspects. (Alhamlan, 2013). The question the researcher tried to find out is whether the educational goals included in the mission statement are highlighted in the curriculum. Analysis of the above data showed that curriculum needed to be changed. The learning outcomes of ELA graduates did not satisfy the needs of students, faculty, and employers or meet the stated objectives. The survey showed that a great percentage of respondents complained about the areas related to critical thinking, reading and listening. Hence, a curriculum that can meet the goal and objectives of ELA had to be chosen. Life ${ }^{\circledR}$ textbooks was chosen to realize the new mission. The learning outcomes of Life ${ }^{\circledR}$ textbooks, which adopts the Common European Framework of Reference (CEFR), correlate to the main goals and objectives of the new mission based on the needs analysis which will also support and be in line with the university mission. (Council of Europe, 2011). Other curricula, such as projects and developing power point presentations, were added to satisfy certain needs identified when analyzing the surveys data.

\subsection{Goals of the New Mission}

1) Preparing students in the Foundation Year for college study since the language of instruction is English. Thus, a student must achieve an English language proficiency that equals the $\mathrm{C} 1$ level in the CEFR to be admitted to university colleges.

2) UBT graduates should have the English language skills required for jobs and professions.

3) A UBT graduate will be able to use English for personal needs and in various social contexts which serves the goal of being an active and constructive member of the community.

\subsection{Faculty}

Analysis of questions \# 5 and 6 in questionnaires 1 and 2 showed that $88 \%$ of beginner level students were satisfied with teachers' performance while $86 \%$ were satisfied of exiting students. To improve the faculty performance, a variety of options were discussed. One option was to develop and follow a strict selection and recruitment policy and procedure. A new position of a recruitment coordinator was established. The coordinator's main duties were to coordinate with human resources the recruitment process starting with ensuring that the hiring ads included the required qualifications, experience and skills which match the duties and responsibilities stated in the job description for the teaching position. A candidate had to appear for an interview and teach a lesson for evaluation. A factor point system was to be developed by the Academic Director to choose suitable candidates.

\subsection{Professional Development}

Responses to the question in questionnaires 1 and 2 regarding students' satisfaction with instructors' performance showed that $85 \%$ of beginner and intermediate students were satisfied while $73 \%$ of students in the advanced level (exiting students) were satisfied. To maintain and improve the quality of instruction, the ELA management 
decided to establish a new unit for professional development of faculty. The unit reviewed what was achieved in the field in the last two years and planned for professional development activities for the coming year. The new activities were planned to take into consideration the methods of teaching that are appropriate to teach the new curriculum. The planned types of professional development were more versified. In the past two years, emphasis was laid on the in-house and within-Kingdom workshops. So, new types were considered and planned while taking in consideration the importance of peer roles in instructors' professional development (Martin \& Double, 1998). These are:

- $\quad$ Peer observation and mentoring

- $\quad$ Studying for higher degrees

- Taking training courses

- $\quad$ Reading EFL books and journals

- Online learning

- Informal discussions and feedback among peers to improve teaching

- Attending and presenting at workshops, conferences and seminars.

Teacher development is still a new area to be investigated in the Saudi context. Peer observation was also planned. Instructors were encouraged to invite peers for feedback and development. This area is a priority when it comes to quality assurance since as Shukri puts it, "Teacher development is still a new area to be researched in the Saudi context." (Shukri, 2014, p. 192). A major concern regarding peer observation in Saudi Arabia and other Arab countries in general, for example, is confusing peer observation with regular ones. Another concern is confusing summative versus informative observations. Collaboration and self-reflection are two main cornerstones of professional development (Ferguson, 2006). These can be enhanced and achieved through certain types of teacher development such as peer observation. In addition, self-reflection is not an end by itself. It, according to Hammersley-Fletcher \& Orsmond (2005) " ... will enhance their (the teachers') understanding of approaches to curriculum teaching styles, students' learning and subject matter" (p. 223). Workshops on using the Moodle, a program package which is available at the ELA, and MyELT provided by NGL were planned.

\subsection{Teaching Approaches}

Another area that needed to be examined and dealt with to fulfil the new mission goals and objectives was the teaching approaches used at the ELA. The communicative approach and the natural method were chosen since they can best deliver the new curricula which is basically notional functional with an emphasis on critical thinking (Gorsuch, 2000) In-house workshops were planned for faculty dealing with such concerns. Faculty members were also encouraged to use on-line programs emailed to them by the professional development unit, a unit which was created as a result of the exercise.

\subsection{Extra-Curricular Activities}

Extracurricular activities such as site visits to factory plants, debates, and camping were planned. Foundation of an English Club at the ELA was also approved by university's management.

\subsection{Collaboration with Teachers of Other Descipliness}

Responses to questions of questionnaire \# 3 (for faculty in other colleges) showed the benefit and necessity to include non-EFL teachers in the process of mission development. Their feedback, especially the feedback related to listening, reading and critical thinking, contributed to decisions related to change of curriculum and professional development of staff.

\subsection{Management Change (Governance)}

In response to question \# 8 in questionnaires 1 and 2, 65\% of the students responded that they never consulted the student affairs staff since this staff member had other duties and responsibilities and had the job title of Assistant Administrator. There was no student affairs unit to go to. Students' complaints were addressed by two or three different staff members and each dealt with these complaints individually without referring to any written policies and procedures. The issues and complaints varied and the consultation and method to solve problems varied too. Hence the necessity to establish a student affairs unit and development of policies and procedures to cater for students' affairs and complaints deemed to be crucial. The project resulted in changes in the governance of ELA. New units, such as the professional development unit and the student affairs unit, were established. Detailed policies and procedures governing student affairs and attendance were developed. The organizational structure was changed along with amendment of job descriptions to specify the new job duties 
and responsibilities required to achieve the stated goals and objectives of the new mission. The idea of shared governance between faculty and administrators was to be examined in the next quarterly plan.

\subsection{Dissemination of the New Mission}

It was decided to disseminate the mission through various channels. Those are:

- $\quad$ Posting the mission on the English Language Academy website.

- Post it on boards placed in corridors and corners of the university buildings.

- Include it in the signatures of ELA faculty and staff.

- Print it on all ELA official correspondence and literature, such as brochures and leaflets.

- Academy webpage and published materials such as the catalog and faculty handbook.

\section{Conclusion}

The self-study process to fulfil the requirements for English language program accreditation from an internationally recognized commission has helped in implementing quality assurance and further maintaining it. The domains of the eleven standards cover require extensive work and activities during and after the self-study period. This is of vital importance for institutions in Saudi Arabia which have English language programs taught at public or private universities in the foundation year in particular. The report shows that the development of a new mission resulted in various changes in all the major areas of the program. These changes were necessary to obtain an accreditation status. The self-study exercise enhanced the academic performance and ensured maintaining quality. The main areas modified or changed to be enhanced included curriculum, teaching approaches, recruitment of faculty and professional development, governance, and student affairs. The curriculum had to be changed to achieve the recommended learning outcomes identified as a result of the needs analysis of the five surveys. The recruitment policy and procedure were amended to recruit the faculty that can deliver and achieve the missions' goals and objectives. In addition, the appropriate type of professional development was planned to cater for the improvement needs of faculty and maintain best practice. The communicative approach was recommended to use although instructors were given the freedom to use other teaching approaches they see fit for the special classroom context. Policies and procedures governing the operation and functions of the new units which were added to the modified organizational chart were developed. A Students' Affairs Unit; a Professional Development Unit and a new position of a Recruitment Coordinator were created. The establishment of these units was necessary to carry out functions required to fulfil the new mission and obtain accreditation. The old job descriptions were reviewed and new job descriptions were developed for the newly created positions. The relationships between management, staff and faculty were more accurately defined and regulated to improve and maintain transparency and fruitful collaboration. The new mission also supports and is aligned to the university mission. The main three goals of the new mission being enhancement of students' English language proficiency to advance their learning abilities at college; the English language competency that enables graduates to compete and become entrepreneurs and leaders in the job market; and to use English for personal well-being and social responsibility. All the above goals are major ones of the university mission.

The new mission is:

"The Mission of the English Language Academy (ELA) at the University of Business and Technology (UBT) is to provide students with the English language skills required for college education as well as the ability to communicate effectively in their professional and social life".

The mission is periodically evaluated and revised yearly. In addition, whenever any major change takes place at the university or academy that affects the program. The mission statement is revisited, revised or changed to adapt to any new needs and requirements that take place. The new mission was written in a simple language accessible to stakeholders. Moreover, it was decided to translate it into Arabic so that parents, sponsors and prospective students can read and understand it. It is aligned with the university's main mission and covers the main goals and objectives of the academy and the university. Universities and institutions which teach EFL in Saudi Arabia are encouraged to go through the self-study exercise. Not only does obtaining program accreditation enhance the ranking and image of the institution, but also maintains quality teaching and results. 


\section{References}

Alhamlan, S. (2013). EFL curriculum and needs analysis: An evaluative study. Retrieved June 17, 2015, from http://files.eric.ed.gov/fulltext/ED542860.pdf

Commission on English Language Program Accreditation standards. (2017). 1001 North Fairfax Street, Suite 630, Alexandria, VA 22314 www.cea-accredit.org

Council of Europe. (2011). Common European Framework of Reference for Languages: Learning, teaching, assessment. Cambridge: Cambridge University Press.

Ferguson, R. (2006). 5 challenges to effective teacher professional development. Journal of Staff Development,

Gorsuch G. J. (2000) EFL educational policies and educational cultures: Influences on teachers' approval of communicative activities.TESOL Quarterly, 34(4), 675-710. https://doi.org/10.2307/3587781

Hammersley-Fletcher, L., \& Orsmond, P. (2005). Reflecting on reflective practices within peer observation. Studies in Higher Education, 30, 2213-224. https://doi.org/10.1080/03075070500043358

Martin, G. A., \& Double, M. J. (1998). Developing Higher Education teaching skills through peer observation and collaborative reflection. Innovations in Education \& Training International, 35(2), 161-170. https://doi.org/10.1080/1355800980350210

Shukri, N. (2014). Female Teachers' Perceptions of Reflective Teaching as a Teacher Development Tool in the Saudi Context. Advances in Language and Literary Studies, 5(5), 192-201.

\section{Copyrights}

Copyright for this article is retained by the author(s), with first publication rights granted to the journal.

This is an open-access article distributed under the terms and conditions of the Creative Commons Attribution license (http://creativecommons.org/licenses/by/4.0/). 